\title{
The Influence Of Information Technology Control Activities On The Financial Statement Audit
}

Ronald J. Daigle, Sam Houston State University

Tim Kizirian, California State University, Chico

L. Dwight Sneathen Jr., Georgia Southern University

\begin{abstract}
This study examines the influence of assessed information technology (IT) control reliability on financial statement audit effort and fees. Since SAS 94 requires auditors to consider an auditee's use of IT controls during audit planning, this study seems highly relevant. Using archived audit workpaper documentation, our results show that IT control strength assessments are inversely associated with control risk assessments, audit hours, and fees. Results also show that both the control risk and IT control strength assessments have similar influence on hours and fees.
\end{abstract}

\section{INTRODUCTION}

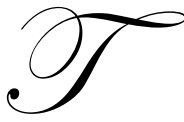

his study examines the influence of assessed information technology (IT) control reliability on both financial statement audit effort and fees. While professional guidance promotes the adjustment of evidence accumulation based on the auditor's level of reliance on internal control, prior archival studies document mixed results regarding the alleged association between assessed internal control reliability and financial statement audit effort and fees (e.g., Bedard and Johnstone 2004; Felix et al. 2001). In addition, prior literature has not directly considered the influence of a client's use of IT on financial statement audit effort and fees. Using archived audit workpaper documentation, we report an inverse relationship between auditor-assessed strength of IT control activities (a proxy for reliance) and the auditor's control risk assessment, financial statement audit hours (a proxy for effort), and fees. More notably, we find that the assessed strength of IT control activities influences audit hours and fees just as much as the control risk assessment.

Professional guidance states that auditors should gain a sufficient understanding of internal control to determine the nature, timing, and extent of tests to be performed on a financial statement audit (e.g., AICPA 1983, AICPA 2001). As IT usage in accounting systems has grown, auditing standards have evolved to embrace its influence on the audit process. When initially issued, SAS 55 (AICPA 1988) acknowledged the existence of computers and controls surrounding their use in the processing of financial information. SAS 78 (AICPA 1995) amended SAS 55 by expanding the discussion of how technology can influence information systems and internal control. Further amending SAS 55, SAS 94 (AICPA 2001) requires auditors to obtain a specific understanding of the affects of IT on control risk which, through the Audit Risk Model (ARM), shapes audit planning decisions. Where these changes affect audit effort, audit fees should be similarly influenced.

We investigate the relationship between reliance on IT control activities and audit effort and fees using archived audit workpaper documentation from a Big 4 firm. Auditees in our data set are identified by the financial statement auditors as being "IT-dependent" because a significant amount of the auditee's financial statement information is electronically initiated, recorded, processed, or reported. Per firm policy, this identification necessitates special consideration of IT in the financial statement audit process. For auditees whose systems are ITdependent, effective audit tests may not be designed without assessing IT control activities (AICPA 2001). The IT control reliability assessment provided here would be considered just one portion of the current Sarbanes Oxley 404 
assessment requirement. The assessment focuses on automated transaction processing controls which at the time was separate from the financial statement audit assessment of control risk.

For the companies in our data set, firm IT auditors provide assessments of the strength of IT control activities to the financial statement auditors prior to the financial statement auditors' control risk assessment made during the planning phase of the audit. We use these assessments as proxies for reliance, which is consistent with prior research that has studied the impact of internal control reliance, in general, on audit effort and fees (e.g., Bedard and Johnstone 2004). Unique from prior studies, however, is our use of actual assessments made during the performance of audits. Prior studies have used control assessments collected through surveys outside of the audit process.

Our results indicate that the IT auditor's assessments of the strength of the IT control activities are inversely related to the financial statement auditor's assessment of control risk. Results also indicate that assessments of the strength of the IT control activities (control risk) are inversely (directly) related to both financial statement audit hours and fees. Our findings also indicate that assessments of the strength of IT control activities have just as much influence as the control risk assessment on audit hours and fees. This last result is possibly due to the greater relevance of IT control activities for preventing, detecting and correcting material financial statement misstatements when a company heavily utilizes IT within their accounting systems (Bagranoff and Vendrzyk 2000; Tucker 2001). Results of our study may imply that when control risk is assessed for companies that heavily utilize IT in their accounting systems, the assessment can be synonymous to an IT control risk assessment.

Our results should be generalizable to the audits of many companies, especially those that must comply with Section 404 of the Sarbanes-Oxley Act of 2002 (SOX). The Section 404 requirement for an annual audit of internal control over financial reporting has led many organizations to spend substantial amounts on IT and document controls over IT to ensure compliance (FEI 2004). Created by SOX, the Public Company Accounting Oversight Board (PCAOB) issued Auditing Standard No. 5 for clarifying the relationship between the audit of internal control and the financial statement audit. Auditing Standard No. 5 state that the attestation on internal control over financial reporting will provide additional control assessment information (including that of IT) for making financial statement audit planning decisions.

Besides the audit implications of our study, the audit savings can be viewed as a measurable return on effective IT investment. Dehning and Richardson (2002) summarize numerous studies investigating whether IT investments generate tangible returns, with results mixed. We know of no study that attempts to identify tangible benefits from investing in IT controls. The savings that can be obtained from investing in IT controls should be of interest to many companies, especially those investing in IT because of SOX.

Our study proceeds as follows. Section two discusses the background and outlines hypotheses. Section three describes the data and empirical tests. Section four provides results and section five summarizes and discusses the implications of findings.

\section{LITERATURE REVIEW AND HYPOTHESES}

\section{Audit Risk}

SAS 47 provides the Audit Risk Model (ARM) as a financial statement audit planning guide. According to the ARM, audit risk has three components: inherent, control, and detection risk. After the auditor determines the acceptable level of both audit risk and detection risk and then assesses both inherent risk and control risk, the necessary nature, timing and extent of audit procedures can be planned. Authoritative guidance on risk assessments identifies certain audit characteristics that are to be considered in inherent, control, and detection risk, but does not clearly indicate the manner in which these factors are to be weighted in the process (e.g., AICPA 1983, AICPA 2001). 
Inherent risk is the likelihood of significant misstatements, ignoring the affect of internal control. Inherent risk assessments take into consideration the external factors, pressures, and forces brought to bear on the entity as well as some internal factors that may influence financial reporting. Inherent risk may relate to conditions or events on a company-wide basis or specific to an audit objective, such as the nature of the account balance or class of transactions. When inherent risk is high, ceteris paribus, a straightforward use of the ARM would suggest that the auditor will perform more testing in order to achieve the desired audit risk.

Control risk is defined as the risk that a material misstatement that could occur in an assertion will not be prevented or detected on a timely basis by internal control (AICPA 1983). Factors considered in the assessment of control risk include the degree of competence of client personnel, levels of oversight (board of director and audit committee activities), the assignment of authority and responsibility, and management's commitment to the process of providing accurate financial information. The control risk assessment requires the auditor to obtain an understanding of internal control. An auditor may assess control risk at the maximum level for audit efficiency purposes, but if the auditor assesses below the maximum level, tests of controls are to be performed. When control risk is high, ceteris paribus, the auditor would not put much reliance on the client's internal control but would rather take a more substantive testing approach. Professional standards (i.e., AICPA 1988) are clear that higher levels of control risk should result in more extensive audit testing in order to achieve the desired audit risk.

Detection risk is the risk of the auditor not detecting a material misstatement in an assertion. Unlike inherent risk and control risk which are independent of the audit, detection relates directly to audit procedures and can be changed at the auditor's discretion. The auditor should set detection risk in response to assessments of inherent risk and control risk to achieve the desired audit risk. The lesser (greater) the inherent risk and control risk that the auditor perceives exists, the greater (lesser) should be detection risk and, therefore, the amount of substantive testing.

\section{Influence Of IT On Internal Control}

As IT has become an integral part of business activities over the last two decades, the potential impact of IT on internal control has been recognized and addressed in professional audit guidance. In amending SAS 55, SAS 78 incorporated the definition and description of internal control from the Internal Control Integrated Framework published by the Committee of Sponsoring Organizations of the Treadway Commission (COSO Framework). Three elements of the internal control structure described in SAS 55 (the control environment, the accounting system, and control procedures) were replaced with the five interrelated components of the COSO Framework: 1) the control environment, 2) risk assessment, 3) control activities, 4) information and communication, and 5) monitoring. SAS 78 required auditors to obtain and document an understanding of each component sufficient to assess control risk and develop substantive audit procedures. Consistent with the COSO Framework, SAS 78 stated that information system control activities can be subcategorized as either general controls or application controls. SAS 78 therefore highlighted the influence of IT on internal control for assessing control risk; however it did not require specific documentation of any consideration of IT.

SAS 94 took the next step by requiring auditors to specifically consider the effect of IT when obtaining an understanding of internal control for assessing control risk and planning an audit engagement. ${ }^{1}$ SAS 94 uses the term "information technology", which denotes "automated means of originating, processing, storing, and communicating information, and includes recording devices, communication systems, computer systems (including hardware and software components and data), and other electronic devices." Noting that information processes may be either manual or automated, SAS 94 states that the control activities component may likewise be either manual or automated. Consistent with SAS 78, automated controls (also referred to as "IT control activities" in Section 43 of SAS 94) are subcategorized as general and application controls.

General controls are defined by SAS 78 as controls "over data center operations, system software acquisition and maintenance, access security, and application system development and maintenance" and applies "to

\footnotetext{
${ }^{1}$ SAS 94 was effective for audit periods beginning June 1, 2001.
} 
mainframe, minicomputer, and end-user environments." General controls are refined in SAS 94 to include "policies and procedures that relate to many applications and support the effective functioning of application controls by helping ensure the continued operation of information systems." Examples provided in SAS 94 include controls over data center and network operations; system software acquisition and maintenance; access security; and application system acquisition, development, and maintenance.

Application controls are defined in SAS 78 as specific "to the processing of individual applications" and helps "ensure that transactions are valid, properly authorized, and completely and accurately processed." Refined in SAS 94, an application control also "relates to the use of IT to initiate, record, process, and report transactions or other financial data." Examples provided in SAS 94 include edit checks of input data; numerical sequence checks; and manual follow-up of exception reports. Together, general and application controls serve to ensure validity, accuracy, and completeness of financial information produced by the system. By being identified, defined, and described in SAS 94, the standard directly implies that general and application controls are a central consideration and assessment for understanding internal control, assessing control risk in the ARM, and making audit planning decisions.

\section{Hypotheses}

While the relationships between internal control reliance and both financial statement audit effort and fees are clear in theory (i.e., the ARM), prior research reports mixed results. Studies using experimental methodologies consistently find that auditors consider internal control assessments when planning audit procedures (e.g., Gaumnitz et al. 1982; Kaplan 1985; Libby et al. 1985; Emby, 1993). Archival studies, however, have not reported such consistent results. Studies such as Bedard (1989), Mock and Wright (1993), O'Keefe et al. (1994), Stein et al. (1994), Hackenbrack and Knechel (1997), and Felix et al. (2001) find that internal control assessments are not related to either planned or actual effort and/or fee decisions, while Willingham and Wright (1985), Kreutzfeldt and Wallace (1986), Messier and Plumlee (1987), Roberts and Wedemeyer (1988), Kreutzfeldt and Wallace (1990), and Bedard and Johnstone (2004) document a significant relationship between internal control assessments and planned or actual audit effort and/or fees.

One aspect consistent across the archival studies cited is the use of surveys outside of the audit process to collect internal control assessment data. The use of data collected outside of the audit process may possibly explain the conflicting results of prior research. Studies using actual workpaper documentation of auditor decisions may provide more definitive insights into the relationships between internal control reliance and audit effort and fees.

Another aspect consistent across the studies cited is that none considered whether a client's use of IT influences financial statement audit decisions. Murthy (1995) and Viator \& Curtis (1998) use experimental methods to show that IT auditors consider IT controls when making IT audit decisions. Daigle et al. (2005) use archived IT audit workpaper documentation to show that an IT auditor's assessment of IT controls influences both IT audit hours and fees. ${ }^{2}$ As internal controls within systems have become more automated, the profession has acknowledged through SAS 94 that IT control activities have a role of importance in the financial statement audit process. The potential impact of IT control activities on financial statement audit decisions has been acknowledged and addressed in professional guidance, but not in academic research. We first examine whether assessed strength of IT control activities has a significant impact on the assessment of control risk:

H1: The strength of IT control activities will be inversely related to control risk.

The profession has long recognized that the control risk assessment should influence the audit effort, and SAS 94 directly implies that IT control activities (general and application controls), through the control risk

\footnotetext{
2 This paper differs from Daigle, et. al. (2005) as it focuses on the effects of the IT controls reliability assessment on the overall financial statement audit. The 2005 paper concluded that well designed internal controls made the assessment process easier resulting in less effort and cost in the assessment process. This paper focuses on the impact of IT control reliability on the overall control risk assessment and subsequent financial statement audit effort and fees.
} 
assessment, should also influence audit effort. If audit effort is influenced, audit fees should also be influenced. We next examine the association between the assessments of control risk and the strength of IT control activities with audit effort and fees:

H2a: Control risk will be directly related to both total financial statement audit effort and fees.

H2b: The strength of IT control activities will be inversely related to both total financial statement audit effort and fees.

\section{PROPRIETARY DATA, VARIABLE MEASUREMENT, AND MODEL SPECIFICATION}

\section{Proprietary Data}

A Big 4 firm provided access to its archived audit workpapers for a given practice office. The use of audit engagements from one particular office provides homogeneity of audit decisions across engagements in our sample. Using a random number generator, 60 audit engagements from 60 different auditees whose systems are IT dependent (as determined by the audit firm) were selected from the office's list of archived engagements from 1996 to 1999. These firms were identified as having a large volume of automated transactions necessitating the IT audit in order to make audit risk assessments. The IT audit team was separate from the financial audit team, and the IT audit assessment was generated prior to the financial statement auditors development of their preliminary audit risk assessments.

This dataset is from a timeframe prior to when auditors were required to obtain an understanding of and document the influence of IT on internal control under both SAS 94 and SOX 404 (for audit periods beginning after June 1, 2001, as per SAS 94). The audit firm was an early adopter of the concepts set forth in SAS 94, and voluntarily considered the impact of IT when planning the engagements in our sample. We believe this strengthens the use of the dataset for this study.

While this assessment is separate from control risk assessment, it is not synonymous with the Sarbanes Oxley 404 assessment. This IT audit assessment focuses solely on the controls surrounding automated processing of financial information. It would be considered a part of the 404 assessment process.

Of those engagements in the randomly chosen sample, 54 auditees are publicly traded. All engagements have a calendar year end, which eliminates potential variation in audit firm resource constraints based on time of year. At the time of the engagement, the firm audited these clients for an average of approximately 7 years. There are no first-year audit engagements in our sample. ${ }^{3}$ The practice office that provided access to the data has a technology-oriented client base, and the randomly selected engagements are clients operating in the biotech or hightech industries.

All 60 engagements received standard unqualified opinions, and none of the auditees have changed their status as going concerns in subsequent periods. No restatements or known allegations of audit failure have been made in subsequent periods for any engagement in the sample. The firm assisted in the coding of variables, and provided a subsequent multi-level review to ensure consistent coding of data. The multi-level review indicated a $100 \%$ convergence among the various coders. Each engagement in the sample includes the financial statement audit global control risk assessment, IT audit global assessments of general and application controls strength, total financial statement audit hours, and financial statement audit fees.

Firm policy at the time of the engagements required financial statement auditors to obtain internal controls understanding and assessments using firm IT auditors when the client's system is IT-dependent. IT auditor assessments of the strength of IT control activities (reliability) are done prior to financial statement auditor assessment of control risk. ${ }^{4}$ The sequential nature of the data-granting firm's auditing process therefore provides a

\footnotetext{
${ }^{3}$ First year audits may require additional work that a continuing audit would not, therefore creating noise in hours and fees.

${ }^{4}$ We acknowledge that the audit is a complex, sequential, and iterative process (Felix and Kinney 1982). It is a judgmental process that allows for the revisiting of controls assessments and testing.
} 
unique opportunity to investigate the potential effect of assessed IT control reliability on the financial statement auditor's control risk assessment, effort, and fees.

\section{Variable Measurement And Model Specification For H1}

To test the impact of assessed IT control reliability on assessed control risk (H1), we employ OLS regression in the following form:

$$
\begin{aligned}
\mathrm{CR}_{\mathrm{i}}= & \beta_{0}+\beta_{1} \mathrm{GEN}_{\mathrm{i}}+\beta_{2} \mathrm{APP}_{\mathrm{i}}+\beta_{3} \log \mathrm{TA}_{\mathrm{i}}+\beta_{4} \mathrm{TENURE}_{\mathrm{i}}+\beta_{5} \mathrm{LEVERAGE}_{\mathrm{i}}+ \\
& \beta_{6} \mathrm{ROA}_{\mathrm{i}}+\beta_{7} \mathrm{PUB}_{\mathrm{i}}+\beta_{8} \mathrm{IND}_{\mathrm{i}}+\beta_{9} \mathrm{YR}_{\mathrm{i}}+\mathrm{e}_{\mathrm{i}}
\end{aligned}
$$

The dependent variable is the control risk assessment (CR), which is documented in the audit workpapers as either "high," "medium," or "low" and are respectively coded 2 for high, 1 for medium, and 0 for low. The assessment of the reliability of IT control activities is composed of two variables, the assessed strength of general and application controls (GEN and APP, respectively). GEN and APP are each documented in the audit workpapers as either "strong," "moderate," or "weak" and are respectively coded 3 for strong, 2 for moderate, and 1 for weak. Firm IT auditors made these assessments consistent with generally accepted IT audit standards and guidelines, including both the COSO Framework and Control Objectives for Information and Related Technology (COBIT), which was released in 1996. With CR as the dependent variable, we expect the coefficients on both GEN and APP to be negative, indicating that the stronger (weaker) the assessment of either IT control activities category, the lower (higher) the assessed control risk for the audit.

We consider a number of specific control variables to minimize the potential of a correlated omitted variable. To control for auditee size, we include the book value of total auditee assets for the year under audit. Prior literature consistently shows that client size has a nonlinear relationship with audit risk assessments (e.g., Francis 1984; Palmrose 1986a, 1986b; Turpen 1990; O'Keefe et al. 1994; Davidson and Gist 1996; Felix et al. 2001; Bedard and Johnstone 2004). To address this issue, we utilize the natural log of total assets (logTA). Larger firms may have more complex systems, which would directly impact inherent risk. However, larger firms may have more resources for providing more internal control. We therefore expect the coefficient for logTA to be negative with respect to its relationship with assessed control risk.

Prior literature notes that the length of the auditor-auditee relationship may affect risk assessments due to learning over time (e.g., Ashton 1991; O'Keefe et al. 1994; Stein et al. 1994). We control for this by including the number of years the auditor has provided the engagement at the time of the audit (TENURE). As a result of the audit process, the auditee should attain an understanding of control deficiencies to be mitigated. This should result in an improvement in the strength of controls over time, resulting in an expected positive coefficient for TENURE.

Prior studies state that the auditee's financial condition can influence audit risk assessments (e.g., O'Keefe et al. 1994; Stein et al. 1994; Johnstone and Bedard 2001; Bedard and Johnstone 2004). Two common control variables for financial condition are LEVERAGE (total liabilities divided by total assets) and ROA (net income divided by total assets). Although a poor financial condition may impact inherent risk, we have no expectation of the sign of the coefficients of these two variables with respect to assessed control risk.

Prior research suggests that the auditor is more likely to be sued if the auditee is publicly held (e.g., St. Pierre and Anderson 1982). Additionally, incentives to override controls to overstate financial standing and results of operations are suggested to be greater for managers of public firms due to market driven compensation structures (e.g., O'Keefe et al. 1994). Further, in order to compensate for the related increase in auditor business risk, public client's system controls are likely to bear greater auditor scrutiny than that of nonpublic companies (e.g., Palmrose 1986a, 1986b; Pearson and Trompeter 1994). We control for this by including PUB, with a 1 assigned to public companies and a 0 for nonpublic. We expect PUB to have a positive coefficient.

Industry membership may influence audit risk assessments (e.g., Stein et al. 1994; Hackenbrack and Knechel 1997; Johnstone and Bedard 2001; Bedard and Johnstone 2004). IND is an indicator variable representing 
the two industry subcategories in our sample ( 0 for biotech and 1 high-tech). To control for potential systematic differences in the manner in which audits are conducted by year, we include YR, a vector of dummy variables with $\mathrm{n}-1$ elements, where $\mathrm{n}$ equals the number of years from which observations are drawn. Because we have no evidence concerning major changes in audit approach by the data-granting firm either between industry groups or over time, we hold no expectation for the coefficient signs for IND and YR.

\section{Variable Measurement And Model Specification For H2}

To test both the impact of assessed control risk (H2a) and assessed IT control reliability (H2b) on both financial statement audit effort and fees, we employ OLS regressions in the following form:

$$
\begin{aligned}
& \log \mathrm{HRS}_{\mathrm{i}}=\beta_{0}+\beta_{1} \mathrm{CR}_{\mathrm{i}}+\beta_{2} \log \mathrm{TA}_{\mathrm{i}}+\beta_{3} \mathrm{TENURE}_{\mathrm{i}}+\beta_{4} \mathrm{LEVERAGE}_{\mathrm{i}}+\beta_{5} \mathrm{ROA}_{\mathrm{i}}+ \\
& \beta_{6} \mathrm{PUB}_{\mathrm{i}}+\beta_{7} \mathrm{IND}_{\mathrm{i}}+\beta_{8} \mathrm{YR}_{\mathrm{i}}+\mathrm{e}_{\mathrm{i}} \\
& \log \mathrm{HRS}_{\mathrm{i}}=\beta_{0}+\beta_{1} \mathrm{GEN}_{\mathrm{i}}+\beta_{2} \mathrm{APP}_{\mathrm{i}}+\beta_{3} \log \mathrm{TA} \mathrm{A}_{\mathrm{i}}+\beta_{4} \mathrm{TENURE}_{\mathrm{i}}+\beta_{5} \mathrm{LEVERAGE}_{\mathrm{i}}+ \\
& \beta_{6} \mathrm{ROA}_{\mathrm{i}}+\beta_{7} \mathrm{PUB}_{\mathrm{i}}+\beta_{8} \mathrm{IND}_{\mathrm{i}}+\beta_{9} \mathrm{YR}_{\mathrm{i}}+\mathrm{e}_{\mathrm{i}} \\
& \operatorname{logFEES} S_{\mathrm{i}}=\beta_{0}+\beta_{1} \mathrm{CR}_{\mathrm{i}}+\beta_{2} \log \mathrm{TA}_{\mathrm{i}}+\beta_{3} \mathrm{TENURE}_{\mathrm{i}}+\beta_{4} \mathrm{LEVERAGE}_{\mathrm{i}}+\beta_{5} \mathrm{ROA}_{\mathrm{i}}+ \\
& \beta_{6} \mathrm{PUB}_{\mathrm{i}}+\beta_{7} \mathrm{IND}_{\mathrm{i}}+\beta_{8} \mathrm{YR}_{\mathrm{i}}+\mathrm{e}_{\mathrm{i}} \\
& \operatorname{logFEES} \mathrm{i}_{\mathrm{i}}=\beta_{0}+\beta_{1} \mathrm{GEN}_{\mathrm{i}}+\beta_{2} \mathrm{APP}_{\mathrm{i}}+\beta_{3} \log \mathrm{TA}_{\mathrm{i}}+\beta_{4} \text { TENURE }_{\mathrm{i}}+\beta_{5} \text { LEVERAGE }_{\mathrm{i}}+ \\
& \beta_{6} \mathrm{ROA}_{\mathrm{i}}+\beta_{7} \mathrm{PUB}_{\mathrm{i}}+\beta_{8} \mathrm{IND}_{\mathrm{i}}+\beta_{9} \mathrm{YR}_{\mathrm{i}}+\mathrm{e}_{\mathrm{i}}
\end{aligned}
$$

The dependent variables are total financial statement audit hours (all engagement hours) as a proxy for effort and total billed financial statement audit fees. The relationship between both auditor effort fees and other variables may be nonlinear. We therefore use the natural log of total financial statement audit hours (logHRS), which is consistent with prior audit effort studies (recent example, Bedard and Johnstone 2004), as well as the natural $\log$ of financial statement audit fees (logFEES), which is consistent with prior audit fee studies (recent example, Felix et al. 2001).

We expect CR in both equations 2 and 4 to have positive coefficients with respect to both audit hours and fees, indicating that the lower (higher) the assessed control risk, lower (higher) is both the number of audit hours and fees. For equations 3 and 5, we expect GEN and APP variables to obtain negative coefficients, indicating that stronger (weaker) IT control activities result in both lower (higher) total audit hours and fees. Coefficients for all control variables in these four regressions are expected to be the same as those for equation 1, except for logTA, LEVERAGE, and ROA. The coefficient for logTA is expected to be positive due to prior literature previously cited indicating a positive relationship between total assets and audit effort and fees. The coefficients for LEVERAGE and ROA are expected to be positive and negative, respectively, because a poor financial condition is associated with greater audit effort and fees, as per prior literature previously cited. 
Table 1

Descriptive Statistics and Spearman Correlations

$\mathbf{N}=60$

$\underline{\text { Panel A: }}$ Descriptive Statistics

\begin{tabular}{|c|c|c|c|c|c|c|}
\hline$\underline{\text { Variable }}$ & Definition & MEAN & $\underline{\text { STD DEV }}$ & QUARTILE \#1 & MEDIAN & QUARTILE \#3 \\
\hline HRS & Total financial statement audit hours & 1,713 & 3,242 & 447 & 695 & 1,591 \\
\hline FEES & Billed financial statement audit fees & $\$ 319,160$ & $\$ 577,000$ & $\$ 80,855$ & $\$ 147,105$ & $\$ 303,532$ \\
\hline $\mathrm{CR}$ & $\begin{array}{l}\text { Financial statement auditor's assessed level of } \\
\text { control risk, where } 2 \text { indicates a high level, } 1 \\
\text { indicates a moderate level, and } 0 \text { indicates a low } \\
\text { level of control risk }\end{array}$ & 0.30 & 0.50 & 0 & 0 & 1 \\
\hline GEN & $\begin{array}{l}\text { IT auditor's assessment of general controls } \\
\text { strength, where } 3 \text { indicates strong, } 2 \text { indicates } \\
\text { moderate, and } 1 \text { for weak levels of general } \\
\text { controls }\end{array}$ & 2.20 & 0.91 & 1 & 3 & 3 \\
\hline APP & $\begin{array}{l}\text { IT auditor's assessment of application controls } \\
\text { strength, where } 3 \text { indicates strong, } 2 \text { indicates } \\
\text { moderate, and } 1 \text { for weak levels of application } \\
\text { controls }\end{array}$ & 2.17 & 0.78 & 2 & 2 & 3 \\
\hline TA & Total assets (in thousands) & $\$ 83,410$ & $\$ 69,579$ & $\$ 26,789$ & $\$ 86,426$ & $\$ 232,756$ \\
\hline TENURE & Number of years firm has performed audit & 6.85 & 4.30 & 4 & 6 & 8 \\
\hline LEVERAGE & Total liabilities divided by total assets & 0.33 & 0.68 & 0.18 & 0.35 & 0.51 \\
\hline ROA & Net income divided by total assets & -0.06 & 0.40 & -0.29 & -0.02 & -0.11 \\
\hline
\end{tabular}

NOTE: Maximum and minimum amounts are omitted to maintain confidentiality of specific auditee information. 
Table 1 (Continued)

Descriptive Statistics and Spearman Correlations $\mathrm{N}=60$

$\underline{\text { Panel B: }}$ : Spearman Correlations

\begin{tabular}{|c|c|c|c|c|c|c|c|c|c|}
\hline & $\operatorname{logHRS}$ & logFEES & CR & GEN & APP & $\log \mathrm{TA}$ & TENURE & LEVERAGE & ROA \\
\hline $\operatorname{logHRS}$ & 1.00 & $\begin{array}{r}0.995 \\
<0.0001\end{array}$ & $\begin{array}{l}-0.082 \\
0.5328\end{array}$ & $\begin{array}{r}0.033 \\
0.8009\end{array}$ & $\begin{array}{l}-0.017 \\
0.8979\end{array}$ & $\begin{array}{r}0.798 \\
<0.0001\end{array}$ & $\begin{array}{r}0.290 \\
0.0248\end{array}$ & $\begin{array}{l}0.115 \\
0.381\end{array}$ & $\begin{array}{r}0.196 \\
0.1336\end{array}$ \\
\hline logFEES & & 1.00 & $\begin{array}{l}-0.016 \\
0.9064\end{array}$ & $\begin{array}{l}-0.013 \\
0.9190\end{array}$ & $\begin{array}{l}-0.073 \\
0.5769\end{array}$ & $\begin{array}{r}0.765 \\
<0.0001\end{array}$ & $\begin{array}{r}0.272 \\
0.0357\end{array}$ & $\begin{array}{r}0.147 \\
0.2626\end{array}$ & $\begin{array}{r}0.200 \\
0.1248\end{array}$ \\
\hline $\mathrm{CR}$ & & & 1.00 & $\begin{array}{r}-0.654 \\
<0.0001\end{array}$ & $\begin{array}{r}-0.738 \\
<0.0001\end{array}$ & $\begin{array}{l}-0.424 \\
0.0007\end{array}$ & $\begin{array}{l}-0.359 \\
0.0049\end{array}$ & $\begin{array}{r}0.230 \\
0.0775\end{array}$ & $\begin{array}{r}-0.0376 \\
0.9773\end{array}$ \\
\hline GEN & & & & 1.00 & $\begin{array}{r}0.565 \\
<0.0001\end{array}$ & $\begin{array}{r}0.396 \\
0.0017\end{array}$ & $\begin{array}{r}0.356 \\
0.0053\end{array}$ & $\begin{array}{l}-0.235 \\
0.0709\end{array}$ & $\begin{array}{l}-0.049 \\
0.7106\end{array}$ \\
\hline APP & & & & & 1.00 & $\begin{array}{r}0.283 \\
0.0284\end{array}$ & $\begin{array}{r}0.269 \\
0.0380\end{array}$ & $\begin{array}{l}-0.160 \\
0.2211\end{array}$ & $\begin{array}{r}0.172 \\
0.1891\end{array}$ \\
\hline $\log \mathrm{TA}$ & & & & & & 1.00 & $\begin{array}{r}0.550 \\
<0.0001\end{array}$ & $\begin{array}{r}0.065 \\
0.6232\end{array}$ & $\begin{array}{r}0.039 \\
0.7651\end{array}$ \\
\hline TENURE & & & & & & & 1.00 & $\begin{array}{r}0.086 \\
0.5145\end{array}$ & $\begin{array}{r}0.086 \\
0.5118\end{array}$ \\
\hline LEVERAGE & & & & & & & & 1.00 & $\begin{array}{c}-0111 \\
0.4004\end{array}$ \\
\hline ROA & & & & & & & & & 1.00 \\
\hline
\end{tabular}




\section{RESULTS}

\section{Descriptive Statistics And Correlations}

Table 1 presents descriptive statistics in Panel A and Spearman Correlations in Panel B. Results for the independent control variables ROA, PUB, IND and YR are not shown in this table or any of the analyses in this study. While our regression results are robust to the inclusion of these variables, none of these four control variables obtain statistical significance in any regression and are therefore removed from the models. ${ }^{5}$

Mean and median numbers of actual audit hours are 1,713 and 695 hours, respectively, while mean and median fees are $\$ 319,160$ and $\$ 147,105$, respectively. The mean and median control risk assessments are 0.30 and 0 , respectively, indicating that auditees in the sample generally have low assessed control risk. The mean and median assessed general controls strength are 2.20 and 3, respectively, while the mean and median assessed application controls strength are 2.17 and 2, respectively. These mean and median assessments indicate that auditees in the sample generally have IT controls at least moderate in strength.

Panel B shows that financial statement hours and fees are essentially perfectly correlated (0.995). This strong relationship has been noted before (e.g., Davis et al. 1993; O'Keefe et al. 1994). This result indicates that the outcomes from testing audit hours and audit fees should be similar. Assessments of CR, GEN, and APP are not significantly correlated with either hours or fees. CR is significantly correlated with both GEN (-0.654) and APP (0.738), providing evidence of inverse relationships as predicted in H1. GEN and APP are also significantly correlated with each other (0.565). This correlation may be expected because, although the assessments are done independent of each other, it is reasonable to expect that a company with strong general controls is likely going to invest resources in similarly strong applications controls, and vice versa.

\section{Results From Testing H1}

Table 2 presents OLS regression results for Equation 1, which tests $\mathrm{H} 1 .^{6}$ Significant negative coefficients are obtained on GEN (-0.140, p-value of 0.0086) and APP $(-0.329$, p-value $<0.0001)$, as predicted. The adjusted $\mathrm{R}^{2}$ for Equation 1 is $62.66 \%$. These results indicate that the assessment of the reliability of IT control activities is inversely related to the assessment of control risk. With respect to control variables shown, only the coefficient for $\log \mathrm{TA}$ is marginally significant with a positive sign as predicted. All remaining control variables fail to be significant.

\section{Results From Testing H2}

Table 3 presents OLS regression results for Equations 3 and 4, which test H2a and b for association with audit hours. Significant coefficients are obtained as predicted on CR $(0.609$, p-value $=0.0004)$, GEN $(-0.285$, pvalue of 0.0033$)$ and APP (-0.170, p-value of 0.0628). Interpretations of significant coefficients help provide insights into the relationships between CR, GEN, and APP with audit hours. Having taken the natural log of hours, as $\mathrm{CR}$ changes by one point on the given three-level scale, audit hours directly change by $60.9 \% .^{7}$ With respect to the assessment of the reliability of IT control activities, as the assessed strength of GEN increases (decreases) by a point on its given three-point scale, audit hours decrease (increase) by $28.5 \%$. Likewise, as the assessed strength of

\footnotetext{
${ }^{5}$ The dataset contains one potential outlier, based on the Dffits suggested cutoff of 2 (SAS Institute Inc. 1990). Exclusion of this one audit would make LEVERAGE, which fails to be significant in any regression model, significant at a $p$-value $<0.07$. Exclusion would also improve the significance of all other results reported. We include the observation as it biases us away from finding our results.

${ }^{6}$ No heteroscedasticity is found in regression models used in this study based on White's (1980) test. Variance Inflation Factors (VIF) also reveal no multicollinearity problems. The highest VIF in any regression models is 1.74 , which is well below the threshold of 10 prescribed by Marquandt (1980).

${ }^{7}$ In a model in which the dependent variable is logged, the interpretation of a coefficient of an independent variable that is not logged is that it is a percentage change in the dependent variable associated with a one-unit change in the independent variable (Johnston and Dinardo 1997).
} 
APP increases (decreases) by a point, audit hours decrease (increase) by $17 \%$. Considering these percentages along with the mean number of audit hours of the sample $(1,713)$, results show that these three assessments can have a dramatic impact on the level of audit effort.

Table 2

OLS Regression Analysis for Testing H1

$\mathrm{CR}_{\mathrm{i}}=\beta_{0}+\beta_{1} \mathrm{GEN}_{\mathrm{i}}+\beta_{2} \mathrm{APP}_{\mathrm{i}}+\beta_{3} \log \mathrm{TA} \mathrm{i}_{\mathrm{i}}+\beta_{4} \mathrm{TENURE}_{\mathrm{i}}+\beta_{5} \mathrm{LEVERAGE}_{\mathrm{i}}+\mathrm{e}_{\mathrm{i}}$

\begin{tabular}{|c|c|c|}
\hline Variable & Predicted Sign & $\begin{array}{r}\text { Coefficient } \\
\text { (p-value) }\end{array}$ \\
\hline Intercept & & $\begin{array}{c}2.108 \\
<0.0001 * * *\end{array}$ \\
\hline GEN & - & $\begin{array}{l}-0.140 \\
0.0086^{* * * *}\end{array}$ \\
\hline APP & - & $\begin{array}{c}-0.329 \\
<0.0001 * * *\end{array}$ \\
\hline $\log \mathrm{TA}$ & - & $\begin{array}{l}-0.042 \\
0.0648^{*}\end{array}$ \\
\hline TENURE & - & $\begin{array}{l}-0.006 \\
0.2474\end{array}$ \\
\hline LEVERAGE & $?$ & $\begin{array}{r}0.074 \\
0.2371\end{array}$ \\
\hline Adjusted $\mathrm{R}^{2}$ & & $62.66 \%$ \\
\hline
\end{tabular}

p-values are one-tailed except for Intercept and LEVERAGE, which are two-tailed.

Levels of significance: $*=<0.10 ; * *=<0.05 ; * * *=<0.01$

Table 4 presents OLS regression results for Equations 4 and 5, which test $\mathrm{H} 2 \mathrm{a}-\mathrm{c}$, for association with audit fees. Results are consistent with those from testing for an association with hours, which should be expected considering the high correlation between hours and fees shown in Panel A of Table 1. Significant coefficients are obtained as predicted on CR (0.733, p-value < 0.0001), GEN (-0.297, p-value of 0.0033) and APP (-0.226, p-value of 0.0259). Interpreting the coefficients, as CR increases (decreases) by a point, audit fees increase (decrease) by $73.3 \%$. With respect to the assessment of the reliability of IT control activities, as the assessed strength of GEN increases (decreases) by a point, audit fees decrease (increase) by $29.7 \%$. Further, as the assessed strength of APP increases (decreases) by a point, audit fees decrease (increase) by $22.6 \%$. With mean fees of $\$ 319,160$ for the sample, these percentages indicate that these three assessments can have a substantial impact on audit fees, just as they do on audit effort.

With respect to control variables shown, only the coefficients for both logTA and TENURE are significant, with signs as predicted for both audit effort and fees. LEVERAGE fails to be significant for either audit effort or fees. 
Table 3

OLS Regression Analyses for Testing $\mathrm{H} 2$

H2a:

$\operatorname{logHRS} \mathrm{i}_{\mathrm{i}}=\beta_{0}+\beta_{1} \mathrm{CR}_{\mathrm{i}}+\beta_{2} \log \mathrm{TA}_{\mathrm{i}}+\beta_{3} \mathrm{TENURE}_{\mathrm{i}}+\beta_{4} \mathrm{LEVERAGE}_{\mathrm{i}}++\mathrm{e}_{\mathrm{i}}$

H2b:

$$
\log \mathrm{HRS}_{\mathrm{i}}=\beta_{0}+\beta_{1} \mathrm{GEN}_{\mathrm{i}}+\beta_{2} \mathrm{APP}_{\mathrm{i}}+\beta_{3} \log \mathrm{TA} \mathrm{i}_{\mathrm{i}}+\beta_{4} \mathrm{TENURE}_{\mathrm{i}}+\beta_{5} \text { LEVERAGE }_{\mathrm{i}}+\mathrm{e}_{\mathrm{i}}
$$

\begin{tabular}{|c|c|c|c|}
\hline Variable & $\begin{array}{c}\text { Predicted } \\
\text { Sign } \\
\end{array}$ & $\begin{array}{c}\text { H2a } \\
\text { Coefficient } \\
\text { (p-value) } \\
\end{array}$ & $\begin{array}{c}\text { H2b } \\
\text { Coefficient } \\
\text { (p-value) }\end{array}$ \\
\hline Intercept & & $\begin{array}{c}-3.922 \\
<0.0001 * * *\end{array}$ & $\begin{array}{l}-2.797 \\
0.0009 * * *\end{array}$ \\
\hline $\mathrm{CR}$ & + & $\begin{array}{c}0.609 \\
0.0004 * * *\end{array}$ & \\
\hline GEN & - & & $\begin{array}{l}-0.285 \\
0.0033 * *\end{array}$ \\
\hline APP & - & & $\begin{array}{l}-0.170 \\
0.0628^{*}\end{array}$ \\
\hline $\log \mathrm{TA}$ & + & $\begin{array}{c}0.590 \\
<0.0001^{* * *}\end{array}$ & $\begin{array}{c}0.592 \\
<0.0001 * * *\end{array}$ \\
\hline TENURE & - & $\begin{array}{l}-0.039 \\
0.0312 * *\end{array}$ & $\begin{array}{l}-0.035 \\
0.0443 * *\end{array}$ \\
\hline LEVERAGE & + & $\begin{array}{l}-0.004 \\
0.5134\end{array}$ & $\begin{array}{l}-0.026 \\
0.5940\end{array}$ \\
\hline Adjusted $\mathrm{R}^{2}$ & & $71.53 \%$ & $73.58 \%$ \\
\hline
\end{tabular}

p-values are one-tailed except for Intercept, which is two-tailed.

Levels of significance: $*=<0.10 ; * *=<0.05 ; * * *=<0.01$

While the variables of interest (CR in equations 2 and 4 and GEN and APP in equations 3 and 5) are significantly associated with both effort and fees, adjusted $\mathrm{R}^{2}$ comparisons provide an interesting result. For both $\operatorname{logHRS}$ and $\log$ FEES, the regressions with GEN and APP explain just as much variation $(73.58 \%$ for effort and $71.32 \%$ for fees) as the regressions with CR (71.53\% for effort and $69.65 \%$ for fees). These results show that as companies invest in and use IT in their accounting systems, assessments of IT control activities are relevant for audit planning purposes. Our pre-SAS 94 results support the requirement put in place by SAS 94 that the auditor's explicit consideration of the impact of IT on internal control influences financial statement audit planning decisions. 
Table 4

OLS Regression Analyses for Testing H2

H2a:

$$
\begin{aligned}
& \operatorname{logFEES} \mathrm{i}_{\mathrm{i}}=\beta_{0}+\beta_{1} \mathrm{CR}_{\mathrm{i}}+\beta_{2} \log \mathrm{TA}_{\mathrm{i}}+\beta_{3} \mathrm{TENURE}_{\mathrm{i}}+\beta_{4} \mathrm{LEVERAGE}_{\mathrm{i}}+\mathrm{e}_{\mathrm{i}} \\
& \log \text { FEES }_{\mathrm{i}}=\beta_{0}+\beta_{1} \mathrm{GEN}_{\mathrm{i}}+\beta_{2} \mathrm{APP}_{\mathrm{i}}+\beta_{3} \log \mathrm{TA}_{\mathrm{i}}+\beta_{4} \mathrm{TENURE}_{\mathrm{i}}+\beta_{5} \text { LEVERAGE }_{\mathrm{i}}+\mathrm{e}_{\mathrm{i}}
\end{aligned}
$$

H2b:

\begin{tabular}{|c|c|c|c|}
\hline Variable & $\begin{array}{c}\text { Predicted } \\
\text { Sign }\end{array}$ & $\begin{array}{c}\text { H2a } \\
\text { Coefficient } \\
\text { (p-value) }\end{array}$ & $\begin{array}{c}\text { H2b } \\
\text { Coefficient } \\
\text { (p-value) }\end{array}$ \\
\hline Intercept & & $\begin{array}{r}1.454 \\
0.1202\end{array}$ & $\begin{array}{c}2.851 \\
0.0011^{* * *}\end{array}$ \\
\hline $\mathrm{CR}$ & + & $\begin{array}{c}0.733 \\
<0.0001 * * *\end{array}$ & \\
\hline GEN & - & & $\begin{array}{l}-0.297 \\
0.0033 * * *\end{array}$ \\
\hline APP & - & & $\begin{array}{l}-0.226 \\
0.0259 * *\end{array}$ \\
\hline $\log \mathrm{TA}$ & + & $\begin{array}{c}0.580 \\
<0.0001^{* * * *}\end{array}$ & $\begin{array}{c}0.577 \\
<0.0001 * * *\end{array}$ \\
\hline TENURE & - & $\begin{array}{l}-0.037 \\
0.0446^{* *}\end{array}$ & $\begin{array}{l}-0.033 \\
0.0606^{*}\end{array}$ \\
\hline LEVERAGE & + & $\begin{array}{r}0.024 \\
0.4192\end{array}$ & $\begin{array}{r}0.010 \\
0.4668\end{array}$ \\
\hline Adjusted $\mathrm{R}^{2}$ & & $69.65 \%$ & $71.32 \%$ \\
\hline
\end{tabular}

p-values are one-tailed except for Intercept, which is two-tailed.

Levels of significance: $*=<0.10 ; * *=<0.05 ; * * *=<0.01$

\section{CONCLUSION}

This study examines the influence of the reliance on IT control activities on both financial statement audit effort and fees. Beginning in 2001, SAS 94 requires financial statement auditors to consider the influence of IT on control risk and audit procedures. SAS 94 was enacted because the profession recognizes that IT can be so pervasive within a company's business activities that it should not be ignored by auditors when planning financial statement audit engagements (Tucker 2001). In this study, we use archived audit documentation obtained from a practice office of a Big 4 firm for a sample of auditees whose systems are deemed by the financial statement auditors to be IT-dependent. Our data set precedes the passage of SAS 94, thereby providing a unique opportunity to study the influence of an auditee's use of IT on the financial statement audit before an auditor's consideration of IT usage was required. 
We find four key results in this study. First, IT control strength assessments by firm IT auditors are directly associated with the control risk assessment by firm financial statement auditors. Second, the control risk assessment is directly associated with both actual audit hours and fees. Third, IT control strength assessments are inversely associated with both actual hours and fees. From an IT investment perspective, this finding shows that a tangible and measurable benefit can be obtained from investing effectively in IT controls. A comparison of the second and third results leads to our fourth finding - IT control strength assessments by firm IT auditors are associated just as much with actual hours and fees as the control risk assessment by firm financial statement auditors. Within our sample, our results indicate that as an IT auditor's assessment of IT control strength increases (decreases) one point on a three-point scale of weak, moderate, and strong, audit effort and fees decrease (increase) by $46 \%$ and $52 \%$, respectively.

Our results show that a company's usage of IT influences audit effort and fees, and that the expected result from following the requirements of SAS 94 is achieved. Our results also indicate that for companies which have ITdependent systems, the assessment of IT control activities may have the same influence on effort and fees as the control risk assessment. This finding could have multiple interpretations.

IT control activities are part of one particular component (control activities) amongst five components (the other four being control environment, risk assessment, information and communication and monitoring) that comprise the COSO framework. The adjusted $\mathrm{R}^{2}$ of the regression model for control risk in this study is $63 \%$. However, respective regression models based on IT control assessments for explaining hours and fees has a slightly greater adjusted $\mathrm{R}^{2}$ than the respective models based on control risk assessments. A strict interpretation of these results indicates an unconsidered and unpriced component of control risk, and implies audit decision inefficiencies.

Another competing interpretation of our results may be that the IT-control assessment for a company whose systems are IT-dependent serves as a surrogate assessment for more than just IT control activities but also for other COSO components. COSO and SAS 94 both recognize that IT can influence each of the five components and that the components are interrelated. With this interpretation, control risk within ARM on a financial statement audit may essentially be an assessment of IT control risk when a company has systems that are IT-dependent. These differing interpretations provide the need for studying further the influence of IT on internal control ald audit decisions.

Our study has certain limitations. All audits in our sample are from the same practice office of the same firm. However, this also strengthens our study because of consistency of audit decision-making within all audits in our sample. Another potential limitation is that financial statement auditors on each engagement in our sample make the control risk assessment and perform audit testing, thereby influencing audit hours and fees. Therefore, the decisions made by financial statement auditors (the control risk assessment, hours worked, fee billed) are not exogenous of each other. However, the IT control strength assessments were made by firm IT auditors, an aspect that strengthens the results of this study. The use of actual audit documentation, as opposed to data collected via surveys, also strengthens the generalizability of our results.

Our results are based on audits of companies whose systems are IT-dependent. Although this may appear to be a limitation, SAS 94 was passed because IT is pervasive within business activities and its effect should not be ignored by auditors. As IT innovations continue in business, companies will only become more entrenched with using IT and relying less on manual procedures. Also, SOX has added new internal control audit requirements on public companies that increase the relevance of IT control assessments. PCAOB Auditing Standard No. 5 states that the internal control audit and financial statement audit, while different, are naturally related to one another and that the results from one should be considered when performing the other. Results from auditing internal control over financial reporting where IT control activities are prevalent will likely be considered when performing the financial statement audit. Our results, therefore, are generalizable to the financial statement audits of many companies, especially those affected by SOX. 


\section{Suggestions For Future Research}

Further research is needed for understanding the relationship between internal control activities (and more specifically IT control activities) and audit decisions. Studying the relationship between the internal control audit and financial statement audit may provide insights into possible changes in the financial statement audit process, as well as insights into the internal control assessment process. Section 404 affected companies are documenting and assessing their systems to ensure compliance and, in the process, investing heavily in IT. IT control activities are likely increasing within systems because of the need to comply with Section 404, thereby likely having a greater impact on audit decisions than that found in this study. The relationship between the two audits therefore requires study.

\section{ACKNOWLEGMENTS}

The authors thank the data-granting assurances firm for their generous provision of data. Funding from the University of Arizona Foundation and Department of Accounting is gratefully acknowledged.

\section{REFERENCES}

1. American Institute of Certified Public Accountants (AICPA). 1983. Audit Risk and Materiality in Conducting an Audit. Statement on Auditing Standards No. 47. New York, NY: AICPA.

2. American Institute of Certified Public Accountants (AICPA). 1988. Internal Control. Statement on Auditing Standards No. 55. New York, NY: AICPA.

3. American Institute of Certified Public Accountants (AICPA). 1995. Consideration of Internal Control in a Financial Statement Audit: An Amendment to Statement on Auditing Standards No. 55. Statement on Auditing Standards No. 78. New York, NY: AICPA.

4. American Institute of Certified Public Accountants (AICPA). 2001. The Effect of Information Technology on the Auditor's Consideration of Internal Control in a Financial Statement Audit. Statemelt on Auditing Standards No. 94. New York, NY: AICPA.

5. Ashton, A. H. 1991. Experience and error frequency knowledge as potential determinants of audit expertise. The Accounting Review 66 (April): 218-239.

6. Bagranoff, N. A., and Vendrzyk, P. V. 2000. The changing role of IS audit among the big five US-based accounting firms. Information Systems Control Journal 5: 33-37.

7. Bedard, J. C. 1989. An archival investigation of audit program planning. Auditing: A Journal of Practice and Theory (Fall): 57-71.

8. Bedard, J. C., and K. M. Johnstone. 2004. Earnings manipulation risk, corporate governance risk, and auditors' planning and pricing decisions. The Accounting Review 79 (April): 277-304.

9. Committee of Sponsoring Organizations of the Treadway Commission (COSO). 1999. Internal ControlIntegrated Framework. New York, NY: COSO.

10. Daigle, R. J., T. Kizirian, and L. D. Sneathen, Jr. 2005. System controls reliability and assessment effort. International Journal of Auditing 9 (March): 79-90.

11. Davidson, R., and W. Gist. 1996. Empirical evidence on the functional relation between audit planning and total audit effort. Journal of Accounting Research 34 (Spring): 111-123.

12. Davis, L. R., D. N. Ricchiute, and G. Trompeter. 1993. Audit effort, audit fees, and the provision of nonaudit services to audit clients. The Accounting Review 68 (January): 135-150.

13. Dehning, B. \& Richardson V. J. 2002. Returns on investments in information technology: a research synthesis. Journal of Information Systems 16 (Spring): 7-30.

14. Emby, C. 1993. Framing effects in professional judgment: the link between auditors' judgments of internal control and substantive testing decisions. Auditing: A Journal of Practice and Thoery (Supplement): 287313.

15. Financial Executives International (FEI). 2004. FEI special survey on sarbanes-oxley section 404 implementation. http://www.fei.org/news/404_july.cfm. 
16. Felix, W. L., A. A. Gramling, and M. J. Maletta. 2001. The contribution of internal audit as a determinant of external audit fees and factors influencing this contribution. Journal of Accounting Research 39 (Autumn): 513-534.

17. Felix, W. L., and Kinney, W. R. 1982. Research in the auditor's opinion formulation process: state of the art. The Accounting Review 57 (April): 245-271.

18. Francis, J. R., 1984. The effect of audit firm size on audit prices: A study of the Australian market. Journal of Accounting and Economics 6: 133-151.

19. Gaumnitz, B., T. Nunamaker, J. Surdick, and M. Thomas. 1982. Auditor consensus in internal control evaluation and audit program planning. Journal of Accounting Research 20 (Autumn): 745-755.

20. Hackenbrack, K. and W. R. Knechel. 1997. Resource allocation decisions in audit engagements. Contemporary Accounting Research (Fall): 481-499.

21. Information Systems Audit and Control Foundation (ISACF). 2002. Control Objectives for Information and Related Technology (COBIT) (3rd edn) Rolling Meadows, IL: ISACF.

22. Johnston, J., and J. DiNardo. 1997. Econometric Methods. Fourth edition. New York, NY: McGraw Hill.

23. Johnstone, K. M., and J. C. Bedard. 2001. Engagement planning, bid pricing, and client response in the market for initial attest engagements. The Accounting Review 76 (April): 199-220.

24. Jones, J. 1991. Earnings management during import relief investigations. Journal of Accounting Research 29 (Autumn): 193-228.

25. Kaplan, S. E. 1985. An examination of the effects of environment and explicit internal control evaluation on planned audit hours. Auditing: A Journal of Practice and Theory (Fall): 12-25.

26. Kreutzfeldt, R. W., and W. A. Wallace. 1986. Error characteristics in audit populations: their profile and relationship to environmental factors. Auditing: A Journal of Practice and Theory (Fall): 20-43.

27. Kreutzfeldt, R. W., and W. A. Wallace. 1990. Control risk assessments: do they relate to errors? Auditing: A Journal of Practice and Theory (Supplement): 1-26.

28. Libby, R., J. T. Artman, and J. J. Willingham. 1985. process, susceptibility, control risk, and audit planning. The Accounting Review (January): 199-211.

29. Marquandt, D. 1980. You should standardize the predictor variables in your regression models. Discussion of: A critique of some ridge regression methods. Journal of the American Statistical Association: 87-91.

30. Messier, W., and D. Plumlee. 1987. The effects of anticipation and frequency of errors on auditors' selection of substantive procedures. Accounting and Business Research 17: 349-358.

31. Mock, T., and A. Wright. 1993. An exploratory study of auditor evidential planning judgments. Auditing: A Journal of Practice and Theory 12 (March): 39-61.

32. Murthy, U. S. 1995. An empirical analysis of risk assessments and computer audit strategy under varying conditions of application stability. Advances in Accounting Information Systems 3: 101-135.

33. O’Keefe, T. B., D. A. Simunic, and M. T. Stein. 1994. The production of audit services: Evidence from a major public accounting firm. Journal of Accounting Research (Autumn): 241-261.

34. Palmrose, Z.V. 1986a. Audit fees and auditor size: further evidence. Journal of Accounting Research 24 (Spring): 97-110.

35. Palmrose, Z.V. 1986b. The effect of nonaudit services on the pricing of audit services: further evidence. Journal of Accounting Research 24 (Autumn): 97-110.

36. Pearson, T., and G. Trompeter. 1994. Competition in the market for audit services: the effects of supplier concentration on audit fees. Contemporary Accounting Research (Summer): 91-114.

37. Public Company Accounting Oversight Board (PCAOB) (2007). Auditing Standard No. 5: An Audit of Internal Control Over Financial Reporting That Is Integrated with An Audit of Financial Statements. Auditing Standard No. 5. Washington, D.C.: PCAOB.

38. Roberts, D. M., and P. D. Wedemeyer. 1988. Assessing the likelihood of financial statement errors using a discriminant model. Journal of Accounting Literature: 133-146.

39. St. Pierre, K. and J. Anderson. 1982. An analysis of audit failures based on documented legal cases. Journal of Accounting, Auditing \& Finance. (Spring): 242-263.

40. SAS Institute Inc. 1990. SAS/STAT User's Guide Version 6, Fourth Edition, Volume 2. Cary, NC: SAS Institute Inc.

41. Stein, M. T., D. A. Simunic, and T. B. O’Keefe. 1994. Industry differences in the production of audit services. Auditing: A Journal of Practice and Theory (Supplement): 128-142. 
42. Tucker, G. 2001. IT and the audit. Journal of Accountancy (September): 41-43.

43. Turpen, R.A. 1990. Differential pricing on auditors' initial engagements: further evidence. Auditing: A Journal of Practice and Theory (Spring): 60-76.

44. Viator, R. E. \& Curtis, M. B. 1998. Computer auditor reliance on automated and non-automated controls as a function of training and experience. Journal of Information Systems 12 (Spring): 19-30.

45. White, H. 1980. A heteroscedasticity-consistent covariance matrix estimator and a test for heteroscedasticity. Econometrica 48: 817-838.

46. Willingham, J. J. and W. F. Wright. 1985. Financial statement errors and internal control judgments. Auditing: A Journal of Practice and Theory (Fall): 57-70.

\section{$\underline{\text { NOTES }}$}


NOTES 